\title{
KARAKTERISTIK DEFORMASI GUNUNG MURIA PERIODE 2010-2014
}

\author{
Ari Nugroho' ${ }^{1)}$ dan Irwan Gumilar ${ }^{2)}$ \\ 1) Pusat Kajian Sistem Energi Nuklir (PKSEN) - BATAN \\ Jl. Kuningan Barat, Mampang Prapatan, Jakarta 12710 \\ Telp./Fax: (021)5204243, E-mail: ari_nugroho@batan.go.id \\ 2) Fakultas Geodesi Institut Teknologi Bandung \\ Gedung LabTek IX C Lantai 4, E-mail: igumilar78@gmail.com
}

\begin{tabular}{|c|c|c|}
\hline Diterima & Diterima dalam bentuk revisi & Disetujui \\
\hline 10 September 2015 & 17 Nopember 2015 & 30 Nopember 2015 \\
\hline
\end{tabular}

\begin{abstract}
ABSTRAK
KARAKTERISTIK DEFORMASI GUNUNG MURIA PERIODE 2010-2014. Kegiatan pemantauan deformasi di Gunung Muria direkomendasikan oleh IAEA untuk dilakukan selama lima tahun. Tujuan dari kegiatan ini untuk mengetahui deformasi tanah di sekitar Muria yang terdiri dari pergeseran regional maupun lokal serta nilai regangan tanah, data ini bermanfaat untuk mendukung aspek keamanan dan keandalan calon tapak dalam rencana pembangunan PLTN (Pembangkit Listrik Tenaga Nuklir) di Semenanjung Muria, Jawa Tengah. Sejak tahun 2010 sampai dengan 2014 telah dilakukan pemantauan pada 5 lokasi BM (Benchmark). yaitu di Mijen, Rahtawu, Perdopo, Cranggang, dan Ketek Putih. Pemantauan dilakukan dengan metode survei GPS secara periodik bekerjasama dengan Fakultas Teknik Jurusan Geodesi ITB. Hasil analisis menggunakan software GAMIT 10.4 dapat disimpulkan bahwa sampai dengan tahun 2014 terjadi pergeseran regional di sekitar Muria yang didominasi oleh pergerakan lempeng (rotasi blok Sunda) dengan kecepatan 2,2 cm/tahun. Pergeseran lokal terjadi di 5 lokasi BM dengan kecepatan 2-3 mm/tahun. Perhitungan regangan diperoleh nilai sebesar $2 \times 10^{-2}$ microstrain/tahun terjadi di wilayah Utara Muria, nilai tersebut lebih tinggi dari nilai regangan yg konsisten (5 $x \quad 10^{-8}$ microstrain/tahun), artinya ada indikasi gerakan tanah.
\end{abstract}

Kata Kunci : deformasi, global positioning system, metode diferensial.

\begin{abstract}
THE CHARACTERIZATION OF MURIA MOUNTAIN DEFORMATION IN THE PERIOD

OF 2010-2104. Deformation monitoring activity for Muria Mountain is recommended by the IAEA to be carried out in five years. The goal of this activity is to identify the soil deformation and strain surrounding Muria regionally and locally, this data is beneficial to support safety and reliability aspect of candidate site for constructing the Nuclear Power Plant in Muria Peninsula. Since the year of 2010 to 2014 the deformation monitoring had been applied in five benchmarks which are Mijen, Rahtawu, Perdopo, Cranggang, and Ketek Putih. The monitoring has been done successfully in collaboration with the faculty of Geodesy ITB. Based on the analysis by using GAMIT 10.4 it can be concluded that until the year of 2014 the regional deformation surrounding the Muria is dominated by plate movement namely Sunda block which has the acceleration as fast as $2.2 \mathrm{~cm} /$ year. The local deformation at the 5 Benchmark indicates the presence of deformation as fast as 2-3 mm/year. The strain measurement demonstrates the presence of the strain rate at Northern Muria as big as $2 \times 10^{-2}$ microstrain/year, which is higher than the number of consistent strain ( $5 \times 10^{-8}$ microstrain/year), this mean there is an indication of deformation.
\end{abstract}

Keywords: deformation, global positioning system, differensial method. 


\section{PENDAHULUAN}

Salah satu kegiatan yang dilakukan dalam aspek keselamatan calon tapak PLTN adalah kajian aktivitas vulkanik Gunung Api. Kegiatan ini mengacu pada kriteria keselamatan yang ditetapkan oleh IAEA (International Atomic energy Agency), dalam dokumen "Review of Status of Site Evaluation Studies at Muria Peninsula NPP Site" Tahun 2006, yang menyebutkan bahwa perlu dilakukan pemantauan deformasi untuk mengetahui aktifitas vulkanik di wilayah Gunung Muria selama lima tahun dengan menggunakan metode survei GPS (Global Positioning System) ${ }^{[1]}$.

Penelitian ini bertujuan untuk menentukan adanya nilai deformasi lokal yang telah dimonitor selama periode 2010-2014 sehingga diperoleh informasi terkini tentang status aktifitas Gunung Muria, yang selanjutnya dapat digunakan sebagai bahan untuk menganalisis bahaya Gunung Muria terhadap calon tapak PLTN.

\section{METODOLOGI}

\subsection{Deformasi}

Deformasi didefinisikan sebagai perubahan bentuk, posisi dan dimensi dari suatu materi atau perubahan kedudukan (pergerakan) suatu materi atau benda baik secara absolut maupun relatif dalam suatu kerangka referensi tertentu akibat suatu gaya yang bekerja pada materi tersebut. Ada dua sifat deformasi, sifat elastik, yaitu apabila suatu materi yang mengalami deformasi akan kembali ke bentuk semula setelah gaya deformasinya tidak bekerja lagi pada materi tersebut dan sifat plastik, yaitu suatu materi yang mengalami deformasi tidak akan kembali kebentuk semula setelah terdeformasi karena efek-efek yang terjadi menempel pada materi tersebut ${ }^{[2]}$.

\subsection{Metode Penelitian}

Prinsip dari metode pemantauan aktivitas gunung berapi dengan metode Survei GPS yaitu pemantauan terhadap perubahan koordinat dari beberapa titik yang mewakili gunung tersebut secara periodik. Pada metode ini, beberapa alat penerima sinyal (receiver) GPS ditempatkan pada beberapa titik pantau yang ditempatkan pada punggung dan puncak gunung yang akan dipantau, serta pada suatu stasiun referensi yang dianggap sebagai titik stabil. Koordinat dari titik-titik pantau tersebut kemudian ditentukan secara teliti dengan GPS, relatif terhadap stasiun referensi, dengan menggunakan metode penentuan posisi diferensial menggunakan data pengamatan fase ${ }^{[3]}$.

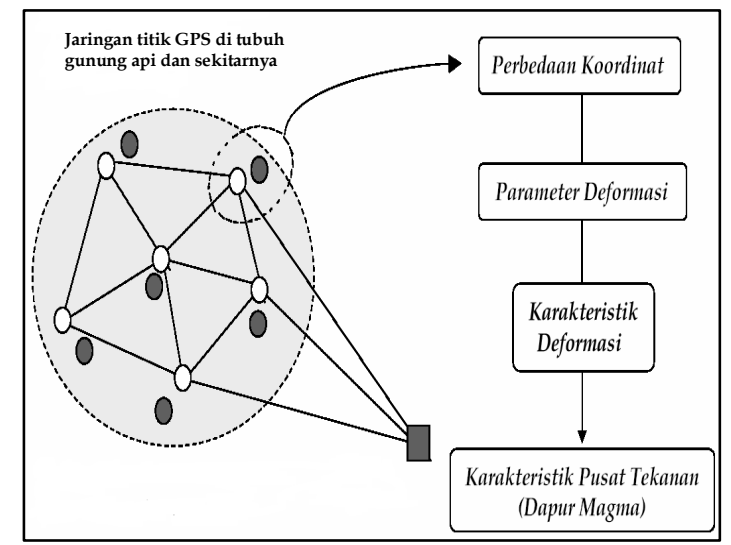

Gambar 1. Pemantauan Deformasi Gunungapi Secara Episodik Dengan Metode Survei GPS 
Selanjutnya dengan mempelajari perubahan koordinat titik-titik pantau tersebut, baik terhadap stasion referensi maupun di antara sesama titik pantau secara periodik, maka karakteristik deformasi dan magmatik gunung berapi yang bersangkutan dapat dipelajari dan dianalisis, seperti yang diilustrasikan pada Gambar 1.

Alir metodologi yang digunakan di dalam penelitian ini seperti yang diilustrasikan pada Gambar 2.

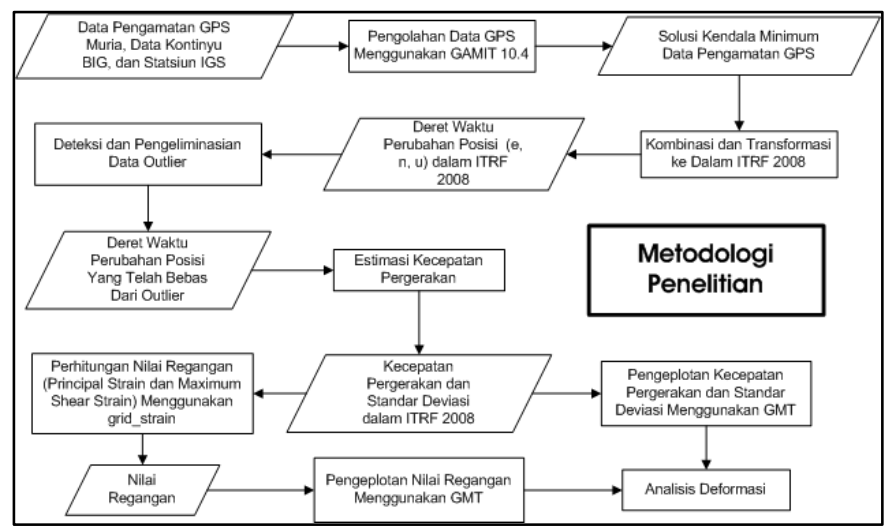

Gambar 2. Diagram Alir Metodologi

Data pengamatan GPS Muria, beberapa data GPS kontinyu yang berada di sekitarnya, dan data stasiun IGS (International Global Navigation Satellite System Service), diolah bersama dengan menggunakan pengolah data GPS GAMIT 10.4. Selanjutnya pada tahap pertama pengolahan data GPS dengan GAMIT 10.4 diperoleh solusi kendala minimum harian untuk semua posisi BM. Proses pendeteksian dan pengeliminasian data outlier dibutuhkan agar deret waktu perubahan posisi terbebas dari outlier sehingga hasil dari pengestimasian kecepatan pergerakan lebih realistis. Kemudian dari hasil vektor kecepatan pergerakan ini digunakan untuk menghitung nilai regangan wilayah muria. Dari kedua informasi ini (vektor kecepatan pergerakan dan nilai regangan) dapat dianalisis pola deformasi yang ada ${ }^{[4]}$.

\subsection{Teknologi Global Positioning System (GPS)}

GPS adalah sistem satelit navigasi dan penentuan posisi yang dimiliki dan dikelola oleh Amerika Serikat. Sistem ini didesain untuk memberikan posisi dan kecepatan tigadimensi serta informasi mengenai waktu, secara kontinyu di seluruh dunia tanpa bergantung waktu dan cuaca. Prinsip penentuan posisi dengan GPS menggunakan metode reseksi jarak, yaitu pengukuran jarak dilakukan secara simultan ke beberapa satelit yang telah diketahui koordinatnya ${ }^{[5]}$.

Metode penentuan posisi dengan GPS terbagi dua, yaitu metode absolut, dan diferensial. Masing-masing metode kemudian dapat dilakukan dengan cara real time dan atau post-processing. Apabila obyek yang ditentukan posisinya diam, maka metodenya disebut statik. Sebaliknya apabila obyek yang ditentukan posisinya bergerak, maka metodenya disebut kinematik. Ada 3 macam tipe alat GPS, dengan masing-masing memberikan tingkat ketelitian (posisi) yang berbeda-beda. Tipe alat GPS pertama adalah tipe navigasi (Handheld, Handy GPS) dengan ketelitian mencapai 3 sampai 6 meter. Tipe alat yang kedua adalah tipe geodetik single frekuensi (tipe pemetaan), yang biasa digunakan dalam survei dan pemetaan dengan ketelitian posisi sekitar sentimeter sampai dengan beberapa desimeter. Tipe terakhir adalah tipe Geodetik dual frekuensi dengan ketelitian hingga mencapai milimeter. 
Ketelitian posisi yang diperoleh akan tergantung pada beberapa faktor yaitu metode penentuan posisi, geometri satelit, tingkat ketelitian data, dan metode pengolahan datanya. GPS memancarkan dua sinyal yaitu frekuensi L1 (1575.42 MHz) dan L2 (1227.60 $\mathrm{MHz}$ ). Ketika sinyal melalui lapisan atmosfer, maka sinyal tersebut akan terganggu oleh konten dari atmosfer tersebut.

Besarnya gangguan disebut bias, apabila bias diabaikan maka dapat memberikan kesalahan posisi sampai dengan orde meter. Kesalahan-kesalahan tersebut contohnya kesalahan orbit satelit, kesalahan jam satelit, kesalahan jam receiver, kesalahan pusat fase antena, dan multipath. Hal-hal lainnya juga ada yang mengiringi kesalahan sistem seperti efek imaging, dan noise[6].

\section{HASIL DAN ANALISIS}

\section{1. $\quad$ Lingkup dan Jadwal Pekerjaan Lapangan}

Lingkup dari pekerjaan lapangan diantaranya pengukuran GPS di 5 benchmark (BM) yang menyebar di wilayah Gunung Muria. Gambar 3 (a) menunjukkan sebaran BM yang telah diukur menggunakan GPS.

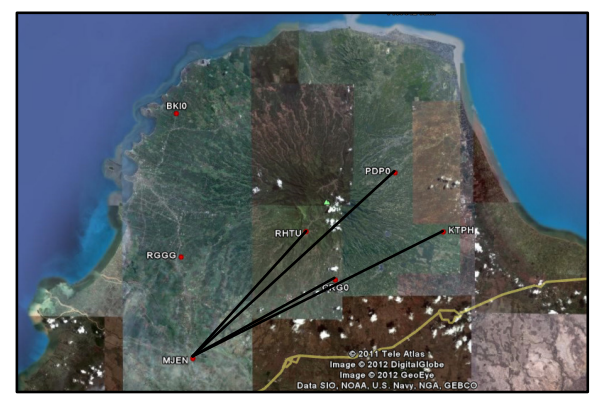

(a). Lokasi benchmark

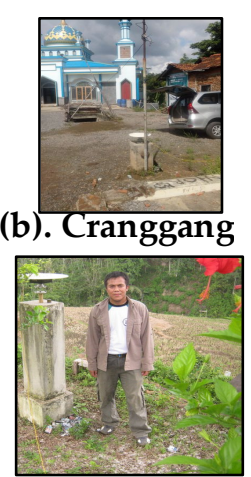

(e). Perdopo

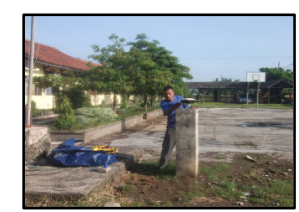

(c). Mijen

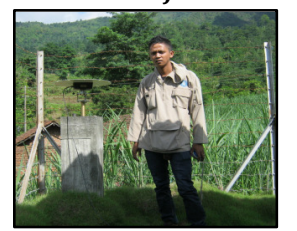

(f). Rahtawu

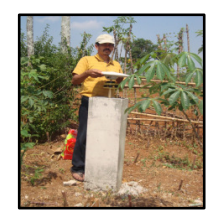

(d). Ketek

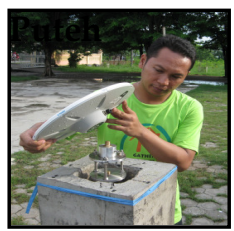

(g). Modified BM

\section{Gambar 3. Benchmark (BM)}

Masing-masing BM sudah dilengkapi dengan modified tribrach ${ }^{[7]}$, sehingga dapat mengurangi kesalahan akibat centring (Gambar $3(\mathrm{~g})$ ).

Survei GPS dilakukan dengan menggunakan receiver GPS tipe geodetik dua frekuensi dengan lama pengamatan secara umum sekitar 12 jam di tiap BM atau stasiun pengamatan. Masing-masing BM diukur selama 2 hari untuk melihat konsistensi hasil pengukuran. Survei telah dilakukan selama 5 kali, yaitu pada Bulan Mei dan Desember 2010 bersama dengan vendor dari Trimble, sedangkan Bulan November 2011, Januari 2013, September 2013 dan Desember 2014 dengan Institut Teknologi Bandung ${ }^{[8]}$.

Proses pelaksanaan suatu survei GPS secara umum akan meliputi beberapa tahapan yaitu: perencanaan dan persiapan, pengamatan (pengumpulan data), pengolahan data, dan pelaporan. Patut ditekankan disini bahwa tingkat kesuksesan pelaksanaan suatu survei GPS akan sangat tergantung dengan tingkat kesuksesan pelaksanaan setiap tahapan pekerjaannya. Di antara tahapan-tahapan tersebut, tahap perencanaan dan persiapan adalah suatu tahap yang sangat menentukan, karena kualitasnya akan sangat menentukan kualitas dari tahap-tahap selanjutnya. Oleh sebab itu tahapan awal ini perlu dilakukan secara baik, sistematis, dan menyeluruh ${ }^{[9]}$. 


\subsection{Pengolahan Data Dan Hasil}

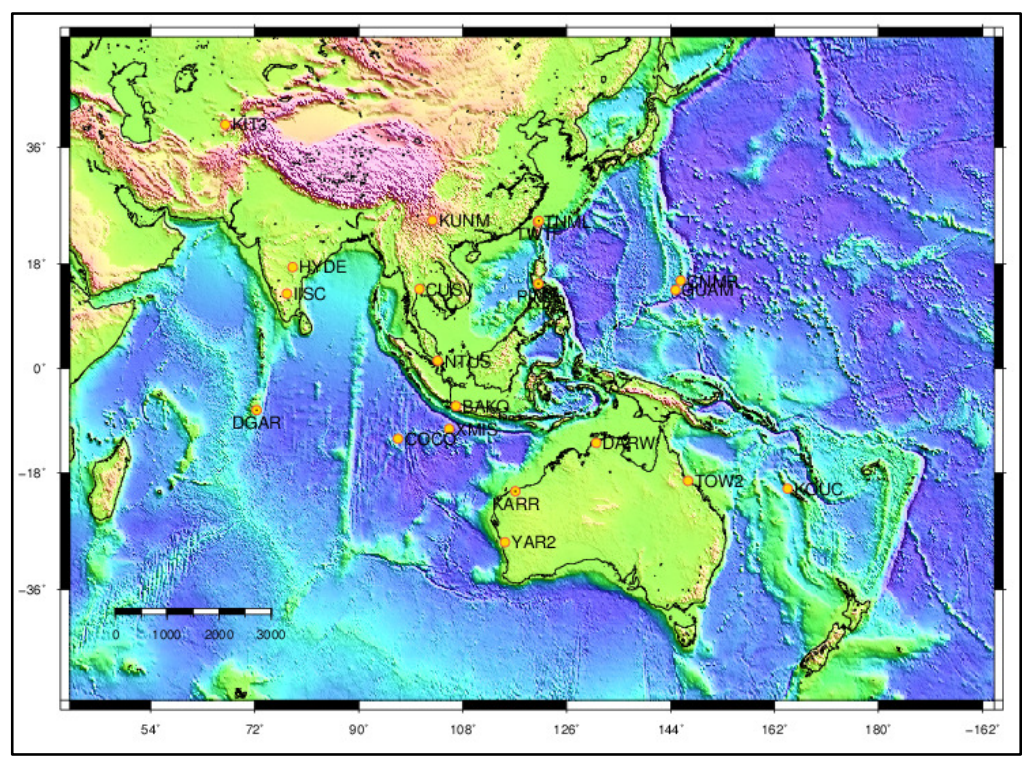

Gambar 4. Jumlah Dan Sebaran Stasiun IGS

Secara geodetik, berdasarkan penelitian sebelumnya dihasilkan lempeng-lempeng utama dan blok di sekitar wilayah penelitian. Hasil tersebut tidak dapat didefinisikan sebagai zona yang bersifat diam atau stabil. Setiap lempeng atau blok memiliki kecepatan pergerakan a priori tertentu yang konsisten setiap tahunnya ${ }^{[10]}$. Tidak adanya zona yang stabil ini menyebabkan tidak memungkinkannya diletakkan suatu stasiun pengamatan GPS pada suatu zona yang stabil sebagai titik ikat bagi stasiun GPS yang lainnya. Dengan alasan ini, strategi pengolahan GPS tipe radial tidak dapat diterapkan pada kasus penelitian ini. Strategi pengolahan yang tepat yang dapat diterapkan dalam penelitian ini adalah strategi pengolahan GPS tipe jaring. Strategi tipe jaring melibatkan stasiun-stasiun pengamatan GPS regional dan global ke dalam jaring pengamatan GPS. Secara praktis, stasiun-stasiun pengamatan GPS ini adalah stasiun GPS pada jaring IGS. Jumlah dan sebaran stasiun IGS yang digunakan dalam penelitian ini dapat dilihat pada Gambar 4.

Sebanyak 19 stasiun IGS di sekitar wilayah Indonesia digunakan untuk memperkuat jaring pengamatan GPS. Data stasiun IGS yang dipilih adalah berdasarkan kriteria bahwa stasiun IGS merepresentasikan zona yang belum terwakili oleh stasiun pengamatan GPS pada objek penelitian (setiap lempeng atau blok yang berada di sekitar obyek penelitian terwakili oleh minimum 2 stasiun IGS), Stasiun IGS dapat memperkuat jaring pengamatan GPS yang telah ada dan deret waktu stasiun IGS memiliki repeatibilitas yang baik ${ }^{[11]}$.

\subsection{Data Pengamatan GPS Yang Digunakan}

Data pengamatan GPS yang digunakan di dalam penelitian ini merupakan data pengamatan GPS episodik tahun 2010 hingga 2014. Secara rinci, data pengamatan GPS ini dapat dilihat pada Tabel 1. 
Tabel 1. Durasi Pengamatan Stasiun GPS Muria Tahun 2010-2014

\begin{tabular}{|c|c|c|c|c|}
\hline Kode Stasiun GPS * & Waktu Mulai & Waktu Berakhir & $\begin{array}{c}\text { Durasi Pengamatan } \\
\text { GPS (jam) }\end{array}$ & Pengamatan ke: \\
\hline \multirow[t]{11}{*}{ MJEN } & $3: 31: 45$ & $11: 46: 45$ & $8: 15: 00$ & Pengamatan ke 1 tahun 2010 \\
\hline & $4: 39: 45$ & 7:15:00 & $2: 35: 15$ & Pengamatan ke 2 tahun 2010 \\
\hline & 5:43:00 & 8:15:00 & $2: 32: 00$ & Pengamatan ke 3 tahun 2010 \\
\hline & $3: 24: 00$ & $14: 44: 00$ & $11: 20: 00$ & Pengamatan ke 1 tahun 2011 \\
\hline & $0: 17: 30$ & $11: 31: 30$ & 11:14:00 & Pengamatan ke 2 tahun 2011 \\
\hline & $2: 43: 15$ & $14: 43: 15$ & 12:00:00 & Pengamatan ke 1 tahun 2013 \\
\hline & $0: 57: 15$ & 14:00:15 & 13:03:00 & Pengamatan ke 2 tahun 2013 \\
\hline & 0:57:00 & $13: 57: 30$ & 13:00:30 & Pengamatan ke 3 tahun 2013 \\
\hline & $3: 55: 00$ & $14: 19: 30$ & $10: 24: 30$ & Pengamatan ke 4 tahun 2013 \\
\hline & 0:0:00 & $14: 19: 15$ & 14:19:15 & Pengamatan ke 1 tahun 2014 \\
\hline & 0:0:00 & $14: 16: 15$ & $14: 16: 19$ & Pengamatan ke 2 tahun 2014 \\
\hline \multirow[t]{10}{*}{ CRGO } & $7: 32: 45$ & 10:03:15 & $2: 30: 30$ & Pengamatan ke 1 tahun 2010 \\
\hline & $6: 21: 45$ & 9:08:15 & $2: 46: 30$ & Pengamatan ke 2 tahun 2010 \\
\hline & 2:03:15 & 4:14:30 & 2:11:15 & Pengamatan ke 3 tahun 2010 \\
\hline & $5: 45: 00$ & $8: 14: 45$ & $2: 29: 45$ & Pengamatan ke 4 tahun 2010 \\
\hline & 4:03:30 & $14: 30: 30$ & $10: 27: 00$ & Pengamatan ke 1 tahun 2011 \\
\hline & 0:46:00 & $11: 57: 45$ & $11: 11: 45$ & Pengamatan ke 2 tahun 2011 \\
\hline & 1:39:30 & 13:02:00 & $11: 22: 30$ & Pengamatan ke 1 tahun 2013 \\
\hline & 1:06:45 & $14: 17: 15$ & $13: 10: 30$ & Pengamatan ke 2 tahun 2013 \\
\hline & $1: 28: 15$ & $13: 39: 30$ & $12: 11: 15$ & Pengamatan ke 1 tahun 2014 \\
\hline & $0: 14: 45$ & $12: 27: 15$ & $12: 12: 30$ & Pengamatan ke 2 tahun 2014 \\
\hline \multirow[t]{11}{*}{$\mathrm{KTPH}$} & $2: 02: 00$ & $4: 38: 45$ & $2: 36: 45$ & Pengamatan ke 1 tahun 2010 \\
\hline & $7: 28: 15$ & 10:10:15 & 2:42:00 & Pengamatan ke 2 tahun 2010 \\
\hline & $2: 02: 45$ & $4: 37: 45$ & 2:35:00 & Pengamatan ke 3 tahun 2010 \\
\hline & 4:14:00 & $14: 42: 00$ & 10:28:00 & Pengamatan ke 1 tahun 2011 \\
\hline & $0: 30: 30$ & 11:33:00 & 11:02:30 & Pengamatan ke 2 tahun 2011 \\
\hline & 1:58:15 & $14: 12: 15$ & $12: 14: 00$ & Pengamatan ke 1 tahun 2013 \\
\hline & $1: 00: 30$ & $14: 08: 45$ & 13:08:15 & Pengamatan ke 2 tahun 2013 \\
\hline & $1: 49: 00$ & $13: 17: 15$ & $11: 28: 15$ & Pengamatan ke 3 tahun 2013 \\
\hline & $0: 56: 30$ & $14: 26: 00$ & $13: 29: 30$ & Pengamatan ke 4 tahun 2013 \\
\hline & 1:19:00 & $13: 31: 45$ & $12: 12: 45$ & Pengamatan ke 1 tahun 2014 \\
\hline & $0: 54: 15$ & $13: 16: 30$ & $12: 22: 15$ & Pengamatan ke 1 tahun 2014 \\
\hline \multirow[t]{9}{*}{ PDPO } & $1: 53: 15$ & 4:55:30 & 3:02:15 & Pengamatan ke 1 tahun 2010 \\
\hline & $8: 00: 45$ & 11:01:15 & 3:00:30 & Pengamatan ke 2 tahun 2010 \\
\hline & $6: 03: 30$ & $9: 05: 30$ & 3:02:00 & Pengamatan ke 3 tahun 2010 \\
\hline & $2: 06: 45$ & $4: 42: 45$ & $2: 36: 00$ & Pengamatan ke 4 tahun 2010 \\
\hline & 2:50:00 & 13:01:15 & 10:11:15 & Pengamatan ke 1 tahun 2011 \\
\hline & $1: 20: 00$ & 13:03:00 & $11: 43: 00$ & Pengamatan ke 1 tahun 2013 \\
\hline & $0: 31: 30$ & $14: 16: 30$ & $13: 45: 00$ & Pengamatan ke 2 tahun 2013 \\
\hline & $0: 59: 00$ & $13: 03: 30$ & $12: 04: 30$ & Pengamatan ke 1 tahun 2014 \\
\hline & 2:32:30 & 13:03:30 & 10:31:00 & Pengamatan ke 2 tahun 2014 \\
\hline \multirow[t]{3}{*}{ RHTU } & $6: 38: 00$ & 9:40:00 & 3:02:00 & Pengamatan ke 1 tahun 2010 \\
\hline & 2:04:00 & $5: 05: 00$ & 3:01:00 & Pengamatan ke 2 tahun 2010 \\
\hline & $3: 06: 00$ & $6: 01: 15$ & $2: 55: 15$ & Pengamatan ke 3 tahun 2010 \\
\hline
\end{tabular}




\begin{tabular}{|c|c|c|c|c|}
\hline Kode Stasiun GPS * & Waktu Mulai & Waktu Berakhiı & $\begin{array}{c}\text { Durasi Pengamatan } \\
\text { GPS (jam) }\end{array}$ & Pengamatan ke: \\
\hline & $2: 05: 15$ & $4: 43: 30$ & $2: 38: 15$ & Pengamatan ke 4 tahun 2010 \\
\hline & $6: 23: 00$ & 9:08:30 & $2: 45: 30$ & Pengamatan ke 5 tahun 2010 \\
\hline & $3: 59: 00$ & 14:59:00 & 11:00:00 & Pengamatan ke 1 tahun 2011 \\
\hline & $1: 36: 00$ & 14:11:15 & $12: 35: 15$ & Pengamatan ke 1 tahun 2013 \\
\hline & $1: 46: 15$ & 14:00:00 & $12: 13: 45$ & Pengamatan ke 2 tahun 2013 \\
\hline & $1: 48: 00$ & 13:48:00 & 12:00:00 & Pengamatan ke 3 tahun 2013 \\
\hline & $0: 53: 30$ & $14: 11: 30$ & $13: 18: 00$ & Pengamatan ke 4 tahun 2013 \\
\hline & $1: 15: 00$ & $13: 18: 30$ & $12: 03: 30$ & Pengamatan ke 1 tahun 2014 \\
\hline & $0: 06: 30$ & $12: 13: 30$ & 12:07:00 & Pengamatan ke 2 tahun 2014 \\
\hline
\end{tabular}

* Keterangan MJEN, CRGO, KTPH, PDPO RHTW merupakan singkatan dari

nama stasiun pengamatan, masing-masing yaitu Mijen, Cranggang,

Ketekputeh, Perdopo dan Rahtawu.

\subsection{Pengolahan Data GPS}

Pengolahan data GPS hasil pengamatan GPS episodik dari tahun 2010 hingga 2014 menggunakan perangkat pengolah data GPS yang bernama GAMIT 10.4. Secara garis besar, parameter solusi yang merupakan hasil pengolahan GAMIT ini di antaranya parameter koordinat stasiun GPS dan matriks kovariansi, algoritma pengestimasian parameterparameter yang ada di dalam pengolahan data pengamatan GPS ditunjukkan pada Gambar 5. Koordinat stasiun GPS diestimasi di dalam sistem koordinat kartesian dengan dua buah solusi yaitu solusi terkendala dan solusi tanpa kendala. Solusi terkendala digunakan sebagai kontrol kualitas sedangkan solusi tanpa kendala digunakan untuk mengeliminasi bias ${ }^{[2]}$.

Hasil utama dari pengolahan data GPS dengan menggunakan GAMIT adalah solusi kendala minimum estimasi parameter dan matriks kovariansinya yang kemudian data dikombinasikan dalam GLOBK untuk mengestimasi posisi stasiun GPS dan kecepatannya serta parameter rotasi bumi dan orbit. Setidaknya terdapat beberapa data yang harus disiapkan pada tahap awal pemrosesan data meliputi koordinat stasiun (L-file), broadcast ephemeris (RINEX navigation file) untuk satelit yang diamati, data pengamatan pseudo-range dan fase, serta informasi pendukung lainnya seperti data meteorologi, tinggi antena, dan skenario penjejakan. Apabila menggunakan opsi parameter orbit-fixed maka diperlukan juga data precise ephemeris (sp3-file). 


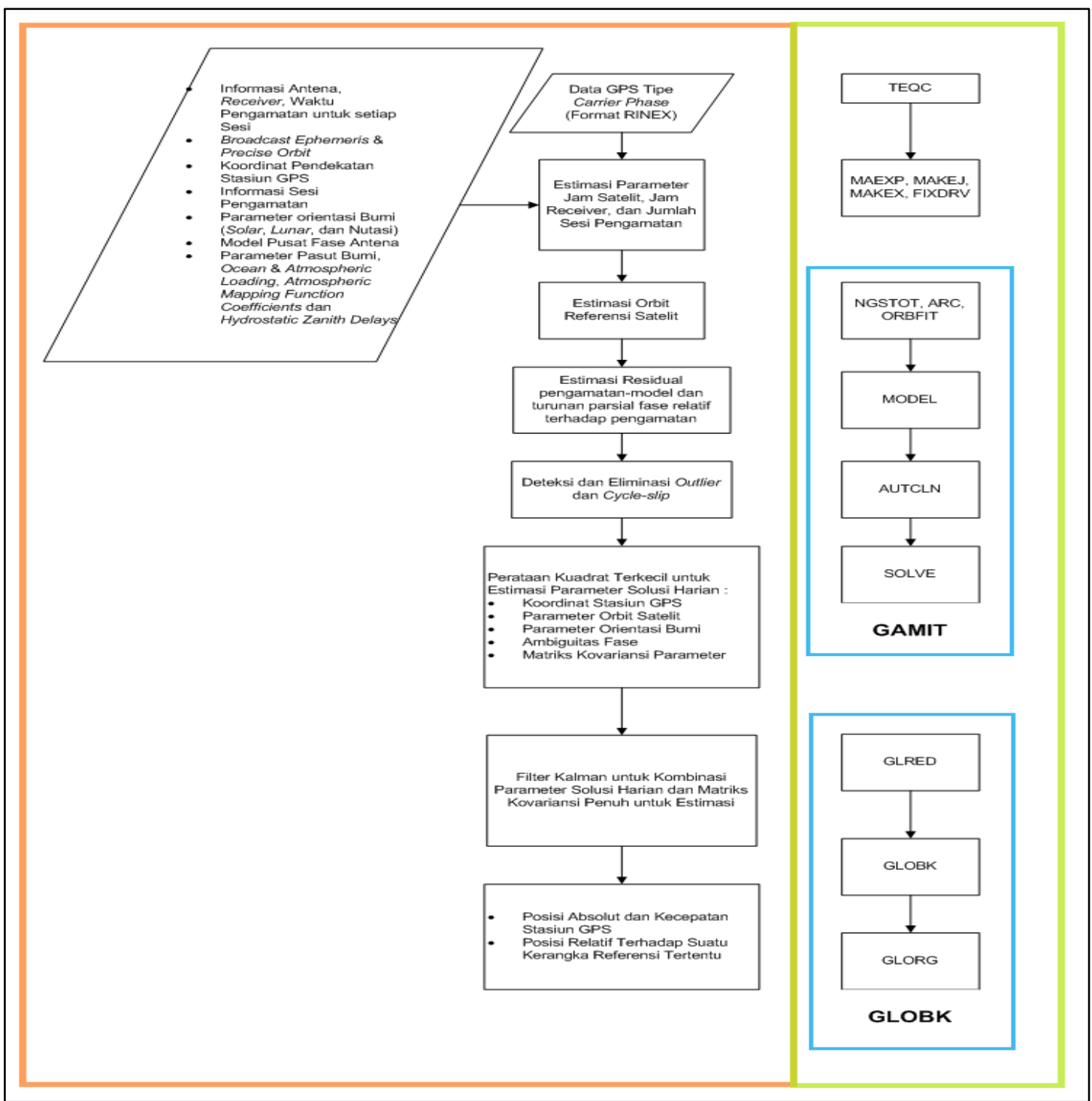

Gambar 5. Estimasi Parameter Pemodelan dan Parameter Solusi dari Data Pengamatan GPS

Pada tahap awal pemrosesan data GPS dalam GAMIT, koordinat stasiun GPS diestimasi sebagai solusi kendala minimum harian (h-file). Solusi dari koordinat stasiun GPS ini tidak didefinisikan dengan baik dalam suatu kerangka referensi. Tetapi, panjang baseline ditentukan secara presisi dalam solusi kendala minimum sehingga jaring GPS dapat dirotasikan dan ditranslasikan sebagai obyek rigid. Solusi harian dari data pengamatan GPS dapat diperoleh dengan menerapkan strategi-strategi pengolahan yang efektif.

Di dalam pengolahan data GPS dengan GAMIT, terdapat tiga parameter yang dapat diestimasi yaitu koordinat satelit, koordinat stasiun pengamatan GPS, dan parameter orientasi bumi. Dalam penelitian ini digunakan strategi baseline yaitu informasi orbit dinyatakan fix. Informasi orbit ini terdiri dari parameter orbit dan parameter orientasi bumi. Maka dalam hal ini kendala minimum hanya diterapkan pada parameter koordinat stasiun pengamatan GPS. Kendala yang diberikan untuk perubahan koordinat pada komponen north, east, dan up sebesar $10 \mathrm{~m}$ dan untuk kecepatan sebesar $1 \mathrm{~m} / \operatorname{tahun}^{[13]}$.

Solusi harian koordinat stasiun pengamatan dihitung dengan menggunakan metode perataan kuadrat terkecil dengan pembobotan berdasarkan data pengamatan double 
differenced dan kombinasi linier bebas ionosfer dari pengamatan fase L1 dan L2. Parameter yang diestimasi untuk solusi harian adalah koordinat stasiun GPS dalam sistem koordinat geosentrik $(X, Y, Z)$ dan ambiguitas fase. Perintah AUTCLN digunakan dalam solusi residual postfit untuk mengkoreksi cycle slip dan mendeteksi outlier untuk setiap interval 30 detik pengamatan (setiap 2 menit untuk solusi akhir). Solusi ambiguitas fase diperoleh dengan menggunakan kendala ionosfer dan data pseudorange. Pada Tabel 2 dapat digambarkan ringkasan stategi analisis pemrosesan data GPS dalam GAMIT :

Tabel 2. Ringkasan Strategi Pengolahan Data GPS Menggunakan GAMIT 10

\begin{tabular}{|c|c|c|}
\hline \multirow{9}{*}{ 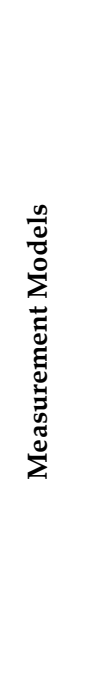 } & Experiment & Baseline \\
\hline & Basic Observable & $\begin{array}{l}\text { Double differenced carrier phase, elevation cut off } 10^{\circ} \text {, sampling rate } 30 \text { detik, } \\
\text { dan pembobotan stasiun dengan model elevasi }\end{array}$ \\
\hline & Modeled observable & $\begin{array}{l}\text { Ambiguity-free dan ambiguity-fixed solutions with LC (using ionospheric } \\
\text { constraints) }\end{array}$ \\
\hline & $\begin{array}{l}\text { Ground antenna phase } \\
\text { center calibration }\end{array}$ & Model IGS05_1421.ATX \\
\hline & $\begin{array}{l}\text { Troposphere a priori } \\
\text { model }\end{array}$ & Zenith delay per 2 jam dan Global Mapping Function (GMF) \\
\hline & Ionosphere & Tidak dimodelkan \\
\hline & Tidal displacement & Ocean loading (FES2004), Pole tide dan Solid Earth tidal (IERS 2003) \\
\hline & $\begin{array}{l}\text { Earth } \quad \text { orientation } \\
\text { variations }\end{array}$ & Fix \\
\hline & GPS attitude model & Yaw attitude model \\
\hline$\frac{\infty}{0}$ & Orbit estimation & $\begin{array}{l}\text { Menggunakan orbit final IGS (menggunakan metode baseline yang hanya } \\
\text { mengestimasi parameter stasiun koordinat), parameter orbit fix, IERS } \\
\text { Bulletin B Earth Orientation Parameters : a priori }\end{array}$ \\
\hline & Solar radiation pressure & Direct radiation : Berne Model (IERS 1992) \\
\hline & Stasiun coordinates & Strategi jaring bebas (tidak ada stasiun yang di-fix) \\
\hline 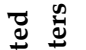 & Receiver clock & Dimodelkan dengan hitung perataan "cubc" \\
\hline 节 & Troposphere & $\begin{array}{l}\text { Zenith delay per-stasiun diestimasi per } 2 \text { jam, aplikasi model } \\
\text { Saastamoinen (1972) untuk nilai a priori model hydrostatic dan wet, model } \\
\text { estimasi : piece-wise linier (standar deviasi a priori adalah } 50 \mathrm{~cm} \text { ) }\end{array}$ \\
\hline
\end{tabular}

Untuk mendapatkan perubahan posisi dari setiap stasiun pengamatan GPS, dilakukan transformasi solusi kendala minimum ke dalam suatu kerangka referensi yang konsisten yaitu ITRF 2008. Kerangka referensi mendefinisikan acuan, skala, dan orientasi dari koordinat geodetik. Kerangka referensi dari solusi harian sebelum ditransformasi adalah kerangka orbit dari epok pengamatan yang dipilih sebagai referensi.

\subsection{Hasil Pengolahan Data GPS}

Hasil pengolahan data GPS untuk setiap stasiun pengamatan GPS dari tahun 2010 hingga 2014, masing-masing diberikan di dalam koordinat kartesian tiga dimensi, koordinat geodetik, dan koordinat toposentrik beserta standar deviasinya (Tabel 3, 4, 5). 
Tabel 3. Koordinat Kartesian 3D Stasiun Pengamatan GPS Hasil GAMIT 10.4 Dalam ITRF 2008

\begin{tabular}{|c|c|c|c|c|c|c|c|c|c|}
\hline \multicolumn{10}{|c|}{ Solusi GAMIT Dalam Sistem Koordinat Kartesian 3D Datum WGS 84 ITRF 2008} \\
\hline Nama & Tahun & Bulan & Hari & $\mathrm{X}(\mathrm{m})$ & $\mathrm{Y}(\mathrm{m})$ & $\mathrm{Z}(\mathrm{m})$ & sd.X $(\mathrm{m})$ & sd.Y $(\mathrm{m})$ & $\operatorname{sd} . Z(\mathrm{~m})$ \\
\hline RHTU & 2010 & 3 & 5 & -2256711.136 & 5920465.440 & -734042.926 & 0.01453 & 0.03182 & 0.00878 \\
\hline RHTU & 2010 & 3 & 6 & -2256711.110 & 5920465.399 & -734042.922 & 0.01606 & 0.03907 & 0.01081 \\
\hline КТРН & 2010 & 5 & 26 & -2273791.875 & 5913492.474 & -734036.908 & 0.0955 & 0.08816 & 0.02598 \\
\hline КТРН & 2010 & 5 & 26 & -2273791.723 & 5913492.025 & -734036.877 & 0.02603 & 0.05292 & 0.01041 \\
\hline RHTU & 2010 & 5 & 27 & -2256711.127 & 5920465.412 & -734042.929 & 0.01511 & 0.02874 & 0.00737 \\
\hline КТРН & 2011 & 11 & 12 & -2273792.198 & 5913493.078 & -734037.012 & 0.0107 & 0.02299 & 0.00638 \\
\hline PDPO & 2011 & 11 & 12 & -2268120.575 & 5916798.128 & -726156.036 & 0.00724 & 0.01415 & 0.00414 \\
\hline CRGO & 2011 & 11 & 12 & -2260027.140 & 5918134.330 & -740479.242 & 0.01351 & 0.03278 & 0.00872 \\
\hline RHTU & 2011 & 11 & 12 & -2256711.530 & 5920466.389 & -734043.051 & 0.01127 & 0.02506 & 0.0062 \\
\hline MJEN & 2011 & 11 & 12 & -2241582.579 & 5923558.498 & -750994.643 & 0.01085 & 0.0234 & 0.00569 \\
\hline RGGG & 2011 & 11 & 12 & -2240681.631 & 5925636.123 & -737397.496 & 0.01101 & 0.02382 & 0.00562 \\
\hline BKIO & 2011 & 11 & 12 & -2240882.642 & 5927930.821 & -718186.698 & 0.00954 & 0.02042 & 0.00481 \\
\hline КТРН & 2011 & 11 & 13 & -2273792.200 & 5913493.066 & -734037.015 & 0.0113 & 0.02187 & 0.00578 \\
\hline PDPO & 2011 & 11 & 13 & -2268120.574 & 5916798.110 & -726156.036 & 0.00895 & 0.01539 & 0.00449 \\
\hline CRGO & 2011 & 11 & 13 & -2260027.137 & 5918134.324 & -740479.244 & 0.01399 & 0.02931 & 0.00771 \\
\hline MJEN & 2011 & 11 & 13 & -2241582.583 & 5923558.504 & -750994.653 & 0.01424 & 0.02787 & 0.00676 \\
\hline RGGG & 2011 & 11 & 13 & -2240681.628 & 5925636.126 & -737397.498 & 0.01461 & 0.03065 & 0.00723 \\
\hline BKIO & 2011 & 11 & 13 & -2240882.639 & 5927930.802 & -718186.695 & 0.01213 & 0.02479 & 0.00595 \\
\hline КТРН & 2013 & 1 & 25 & -2273792.232 & 5913493.054 & -734037.023 & 0.00771 & 0.01628 & 0.00497 \\
\hline RHTU & 2013 & 1 & 25 & -2256711.118 & 5920465.183 & -734042.916 & 0.00748 & 0.01691 & 0.00491 \\
\hline MJEN & 2013 & 1 & 25 & -2241582.600 & 5923558.454 & -750994.649 & 0.00903 & 0.01968 & 0.00503 \\
\hline КТРН & 2013 & 1 & 26 & -2273792.233 & 5913493.048 & -734037.021 & 0.00692 & 0.01516 & 0.00458 \\
\hline RHTU & 2013 & 1 & 26 & -2256711.116 & 5920465.175 & -734042.918 & 0.00791 & 0.01832 & 0.00527 \\
\hline MJEN & 2013 & 1 & 26 & -2241582.601 & 5923558.456 & -750994.654 & 0.00767 & 0.01689 & 0.00442 \\
\hline PDPO & 2013 & 9 & 25 & -2268120.618 & 5916798.057 & -726156.053 & 0.00948 & 0.01873 & 0.00476 \\
\hline RHTU & 2013 & 9 & 25 & -2256711.591 & 5920466.377 & -734043.076 & 0.0113 & 0.02357 & 0.00586 \\
\hline MJEN & 2013 & 9 & 25 & -2241582.622 & 5923558.459 & -750994.665 & 0.00927 & 0.01825 & 0.00451 \\
\hline PDPO & 2013 & 9 & 26 & -2268120.631 & 5916798.080 & -726156.052 & 0.0128 & 0.03043 & 0.00658 \\
\hline RHTU & 2013 & 9 & 26 & -2256711.590 & 5920466.345 & -734043.072 & 0.01149 & 0.0238 & 0.00602 \\
\hline MJEN & 2013 & 9 & 26 & -2241582.620 & 5923558.450 & -750994.657 & 0.01273 & 0.02502 & 0.0062 \\
\hline CRGO & 2014 & 12 & 16 & -2260027.197 & 5918134.284 & -740479.274 & 0.01920 & 0.04475 & 0.0110 \\
\hline PDPO & 2014 & 12 & 16 & -2268120.658 & 5916798.121 & -726156.066 & 0.01151 & 0.02782 & 0.00631 \\
\hline RHTU & 2014 & 12 & 16 & -2256711.621 & 5920466.415 & -734043.092 & 0.01134 & 0.02653 & 0.00650 \\
\hline КТРН & 2014 & 12 & 16 & -2273791.802 & 5913491.811 & -734036.886 & 0.00911 & 0.02153 & 0.00589 \\
\hline MJEN & 2014 & 12 & 16 & -2241582.660 & 5923558.504 & -750994.688 & 0.00942 & 0.01916 & 0.00448 \\
\hline CRGO & 2014 & 12 & 17 & -2260027.173 & 5918134.242 & -740479.266 & 0.01712 & 0.03863 & 0.00941 \\
\hline PDPO & 2014 & 12 & 17 & -2268120.656 & 5916798.087 & -726156.071 & 0.00997 & 0.02442 & 0.00567 \\
\hline RHTU & 2014 & 12 & 17 & -2256711.613 & 5920466.402 & -734043.087 & 0.01718 & 0.04182 & 0.00937 \\
\hline КТРН & 2014 & 12 & 17 & -2273791.799 & 5913491.824 & -734036.890 & 0.01060 & 0.02303 & 0.00646 \\
\hline MJEN & 2014 & 12 & 17 & -2241582.652 & 5923558.490 & -750994.683 & 0.01062 & 0.02281 & 0.00502 \\
\hline
\end{tabular}


Tabel 4. Koordinat Geodetik Stasiun Pengamatan GPS Hasil GAMIT 10.4 Dalam ITRF 2008

\begin{tabular}{|c|c|c|c|c|c|c|c|c|c|}
\hline \multicolumn{10}{|c|}{ Solusi GAMIT Dalam Sistem Koordinat Geodetik Datum WGS 84 ITRF 2008} \\
\hline $\begin{array}{l}\text { Nama } \\
\text { Stasiun }\end{array}$ & Tahun & Bulan & Hari & $\begin{array}{r}\text { Lintang } \\
\text { (derajat) }\end{array}$ & Bujur (derajat) & $\begin{array}{c}\text { Tinggi } \\
\text { Ellipsoid (m) }\end{array}$ & $\begin{array}{l}\text { Sd.Lintang } \\
\text { (mili-second) }\end{array}$ & $\begin{array}{c}\text { sd.Bujur } \\
\text { (mili- } \\
\text { second) }\end{array}$ & $\begin{array}{c}\text { sd.Tinggi } \\
\text { Ellipsoid } \\
(\mathrm{m})\end{array}$ \\
\hline RHTU & 2010 & 3 & 5 & -6.6525677456 & 110.8654076101 & 507.548 & 75 & 91.6 & 0.0336 \\
\hline RHTU & 2010 & 3 & 6 & -6.6525677543 & 110.8654075206 & 507.501 & 78.9 & 103.2 & 0.04115 \\
\hline КТРН & 2010 & 5 & 26 & -6.6529380671 & 111.0322076652 & 104.463 & 203.6 & 915.4 & 0.08252 \\
\hline КТРН & 2010 & 5 & 26 & -6.6529382846 & 111.0322078378 & 103.990 & 89.5 & 188.4 & 0.05525 \\
\hline RHTU & 2010 & 5 & 27 & -6.6525678004 & 110.8654076239 & 507.520 & 54 & 77.1 & 0.03162 \\
\hline КТРН & 2011 & 11 & 12 & -6.6529382924 & 111.0322084290 & 105.150 & 47.5 & 61.8 & 0.02468 \\
\hline PDPO & 2011 & 11 & 12 & -6.5810544618 & 110.9736169105 & 242.671 & 32.5 & 51.4 & 0.01498 \\
\hline CRGO & 2011 & 11 & 12 & -6.7114168702 & 110.9009412038 & 267.291 & 60.5 & 70.5 & 0.03503 \\
\hline RHTU & 2011 & 11 & 12 & -6.6525677916 & 110.8654078837 & 508.583 & 45.5 & 61.1 & 0.02687 \\
\hline MJEN & 2011 & 11 & 12 & -6.8074178674 & 110.7275566849 & 31.366 & 44.1 & 62.1 & 0.02502 \\
\hline RGGG & 2011 & 11 & 12 & -6.6835929291 & 110.7132854314 & 47.484 & 44.4 & 63.6 & 0.02542 \\
\hline BKIO & 2011 & 11 & 12 & -6.5087270894 & 110.7076474931 & 43.550 & 38.1 & 58.1 & 0.02172 \\
\hline КТРH & 2011 & 11 & 13 & -6.6529383281 & 111.0322084859 & 105.140 & 43.9 & 71.5 & 0.02351 \\
\hline PDPO & 2011 & 11 & 13 & -6.5810544845 & 110.9736169561 & 242.654 & 35 & 63.2 & 0.01653 \\
\hline CRGO & 2011 & 11 & 13 & -6.7114169001 & 110.9009411959 & 267.285 & 55.7 & 79.5 & 0.0316 \\
\hline MJEN & 2011 & 11 & 13 & -6.8074179546 & 110.7275567052 & 31.374 & 52.4 & 82.4 & 0.03014 \\
\hline RGGG & 2011 & 11 & 13 & -6.6835929422 & 110.7132853931 & 47.486 & 57.9 & 86 & 0.03276 \\
\hline BKIO & 2011 & 11 & 13 & -6.5087270844 & 110.7076475263 & 43.531 & 46.6 & 74.3 & 0.02651 \\
\hline КТРН & 2013 & 1 & 25 & -6.6529383968 & 111.0322087991 & 105.141 & 37.3 & 42.3 & 0.0176 \\
\hline RHTU & 2013 & 1 & 25 & -6.6525679102 & 110.8654082796 & 507.302 & 38 & 45 & 0.01798 \\
\hline MJEN & 2013 & 1 & 25 & -6.8074179577 & 110.7275570046 & 31.333 & 39.1 & 46.3 & 0.02118 \\
\hline КТРН & 2013 & 1 & 26 & -6.6529383867 & 111.0322088264 & 105.136 & 35.3 & 39.9 & 0.01624 \\
\hline RHTU & 2013 & 1 & 26 & -6.6525679379 & 110.8654082952 & 507.294 & 40.4 & 46.4 & 0.01948 \\
\hline MJEN & 2013 & 1 & 26 & -6.8074180057 & 110.7275570079 & 31.335 & 34.4 & 40.3 & 0.01815 \\
\hline PDPO & 2013 & 9 & 25 & -6.5810546748 & 110.9736175020 & 242.623 & 36 & 59.7 & 0.02009 \\
\hline RHTU & 2013 & 9 & 25 & -6.6525680031 & 110.8654084369 & 508.597 & 42.4 & 64.8 & 0.02538 \\
\hline MJEN & 2013 & 9 & 25 & -6.8074180945 & 110.7275571746 & 31.348 & 35.7 & 60.3 & 0.01947 \\
\hline PDPO & 2013 & 9 & 26 & -6.5810546380 & 110.9736175389 & 242.649 & 48.1 & 73.6 & 0.03223 \\
\hline RHTU & 2013 & 9 & 26 & -6.6525679955 & 110.8654085324 & 508.566 & 44.8 & 73 & 0.02539 \\
\hline MJEN & 2013 & 9 & 26 & -6.8074180332 & 110.7275571919 & 31.337 & 47.3 & 76.2 & 0.02697 \\
\hline CRGO & 2014 & 12 & 16 & -6.7114171818 & 110.9009418402 & 267.273 & 76.5 & 78.3 & 0.04843 \\
\hline PDPO & 2014 & 12 & 16 & -6.5810547166 & 110.9736176371 & 242.698 & 51.4 & 61.9 & 0.02943 \\
\hline RHTU & 2014 & 12 & 16 & -6.6525681016 & 110.8654085659 & 508.644 & 49.5 & 56.4 & 0.02838 \\
\hline КТРН & 2014 & 12 & 16 & -6.6529385438 & 111.0322092014 & 103.820 & 45.4 & 52.1 & 0.02286 \\
\hline MJEN & 2014 & 12 & 16 & -6.8074182417 & 110.7275573533 & 31.405 & 32.8 & 28.0 & 0.02077 \\
\hline CRGO & 2014 & 12 & 17 & -6.7114171648 & 110.9009417697 & 267.225 & 65.5 & 69.7 & 0.04197 \\
\hline PDPO & 2014 & 12 & 17 & -6.5810547963 & 110.9736177252 & 242.667 & 47.2 & 57.1 & 0.02570 \\
\hline RHTU & 2014 & 12 & 17 & -6.6525680747 & 110.8654085438 & 508.629 & 70.0 & 74.6 & 0.04475 \\
\hline КТРH & 2014 & 12 & 17 & -6.6529385686 & 111.0322091343 & 103.832 & 49.9 & 58.4 & 0.02474 \\
\hline MJEN & 2014 & 12 & 17 & -6.8074182150 & 110.7275573320 & 31.38979 & 27.8 & 31.9 & 0.02458 \\
\hline
\end{tabular}


Tabel 5 . Koordinat Toposentrik Stasiun Pengamatan GPS Hasil GAMIT 10.4 dalam ITRF 2008

\begin{tabular}{|c|c|c|c|c|c|c|c|c|c|}
\hline \multicolumn{10}{|c|}{ Solusi GAMIT Dalam Sistem Koordinat Toposentrik Datum WGS 84 ITRF 2008} \\
\hline $\begin{array}{l}\text { Nama } \\
\text { Stasiun }\end{array}$ & Tahun & Bulan & Hari & Utara $(\mathrm{m})$ & Timur $(\mathrm{m})$ & $U p(\mathrm{~m})$ & sd.Utara $(\mathrm{m})$ & sd.Timur (m) & sd.Up $(\mathrm{m})$ \\
\hline RHTU & 2010 & 3 & 5 & -740560.454 & 12258392.153 & 507.548 & 0.00835 & 0.01013 & 0.0336 \\
\hline RHTU & 2010 & 3 & 6 & -740560.455 & 12258392.143 & 507.501 & 0.00879 & 0.01141 & 0.04115 \\
\hline КТPH & 2010 & 5 & 26 & -740601.678 & 12276835.241 & 104.463 & 0.02267 & 0.10121 & 0.08252 \\
\hline КТРН & 2010 & 5 & 26 & -740601.702 & 12276835.260 & 103.990 & 0.00997 & 0.02084 & 0.05525 \\
\hline RHTU & 2010 & 5 & 27 & -740560.460 & 12258392.154 & 507.520 & 0.00601 & 0.00853 & 0.03162 \\
\hline КТРH & 2011 & 11 & 12 & -740601.703 & 12276835.326 & 105.150 & 0.00528 & 0.00683 & 0.02468 \\
\hline PDPO & 2011 & 11 & 12 & -732599.632 & 12272136.109 & 242.671 & 0.00361 & 0.00568 & 0.01498 \\
\hline CRGO & 2011 & 11 & 12 & -747111.508 & 12260812.705 & 267.291 & 0.00673 & 0.0078 & 0.03503 \\
\hline RHTU & 2011 & 11 & 12 & -740560.459 & 12258392.183 & 508.583 & 0.00507 & 0.00676 & 0.02687 \\
\hline MJEN & 2011 & 11 & 12 & -757798.291 & 12239250.029 & 31.366 & 0.00491 & 0.00686 & 0.02502 \\
\hline RGGG & 2011 & 11 & 12 & -744014.162 & 12240784.905 & 47.484 & 0.00494 & 0.00703 & 0.02542 \\
\hline BKIO & 2011 & 11 & 12 & -724548.185 & 12244479.454 & 43.550 & 0.00424 & 0.00643 & 0.02172 \\
\hline $\mathrm{KTPH}$ & 2011 & 11 & 13 & -740601.707 & 12276835.332 & 105.140 & 0.00488 & 0.00791 & 0.02351 \\
\hline PDPO & 2011 & 11 & 13 & -732599.634 & 12272136.115 & 242.654 & 0.00389 & 0.00699 & 0.01653 \\
\hline CRGO & 2011 & 11 & 13 & -747111.512 & 12260812.704 & 267.285 & 0.0062 & 0.00879 & 0.0316 \\
\hline MJEN & 2011 & 11 & 13 & -757798.300 & 12239250.031 & 31.374 & 0.00583 & 0.00911 & 0.03014 \\
\hline RGGG & 2011 & 11 & 13 & -744014.163 & 12240784.900 & 47.486 & 0.00644 & 0.00951 & 0.03276 \\
\hline BKIO & 2011 & 11 & 13 & -724548.185 & 12244479.457 & 43.531 & 0.00519 & 0.00822 & 0.02651 \\
\hline $\mathrm{KTPH}$ & 2013 & 1 & 25 & -740601.715 & 12276835.366 & 105.141 & 0.00415 & 0.00468 & 0.0176 \\
\hline RHTU & 2013 & 1 & 25 & -740560.472 & 12258392.227 & 507.302 & 0.00423 & 0.00497 & 0.01798 \\
\hline MJEN & 2013 & 1 & 25 & -757798.301 & 12239250.064 & 31.333 & 0.00436 & 0.00512 & 0.02118 \\
\hline $\mathrm{KTPH}$ & 2013 & 1 & 26 & -740601.713 & 12276835.369 & 105.136 & 0.00393 & 0.00442 & 0.01624 \\
\hline RHTU & 2013 & 1 & 26 & -740560.475 & 12258392.229 & 507.294 & 0.0045 & 0.00512 & 0.01948 \\
\hline MJEN & 2013 & 1 & 26 & -757798.306 & 12239250.065 & 31.335 & 0.00383 & 0.00446 & 0.01815 \\
\hline PDPO & 2013 & 9 & 25 & -732599.655 & 12272136.175 & 242.623 & 0.00401 & 0.0066 & 0.02009 \\
\hline RHTU & 2013 & 9 & 25 & -740560.483 & 12258392.244 & 508.597 & 0.00472 & 0.00717 & 0.02538 \\
\hline MJEN & 2013 & 9 & 25 & -757798.316 & 12239250.083 & 31.348 & 0.00397 & 0.00667 & 0.01947 \\
\hline PDPO & 2013 & 9 & 26 & -732599.651 & 12272136.179 & 242.649 & 0.00535 & 0.00814 & 0.03223 \\
\hline RHTU & 2013 & 9 & 26 & -740560.482 & 12258392.255 & 508.566 & 0.00499 & 0.00807 & 0.02539 \\
\hline MJEN & 2013 & 9 & 26 & -757798.309 & 12239250.085 & 31.337 & 0.00527 & 0.00842 & 0.02697 \\
\hline CRGO & 2014 & 12 & 16 & -747111.543 & 12260812.775 & 267.274 & 0.00851 & 0.00866 & 0.04843 \\
\hline PDPO & 2014 & 12 & 16 & -732599.653 & 12272136.175 & 242.632 & 0.00572 & 0.00684 & 0.02943 \\
\hline RHTU & 2014 & 12 & 16 & -740560.494 & 12258392.258 & 508.566 & 0.00551 & 0.00624 & 0.02838 \\
\hline КТРН & 2014 & 12 & 16 & -740601.731 & 12276835.410 & 103.821 & 0.00505 & 0.00576 & 0.02286 \\
\hline MJEN & 2014 & 12 & 16 & -757798.316 & 12239250.082 & 31.349 & 0.00416 & 0.00524 & 0.02077 \\
\hline CRGO & 2014 & 12 & 17 & -747111.541 & 12260812.767 & 267.225 & 0.00729 & 0.00771 & 0.04197 \\
\hline PDPO & 2014 & 12 & 17 & -732599.651 & 12272136.177 & 242.643 & 0.00525 & 0.00632 & 0.02570 \\
\hline RHTU & 2014 & 12 & 17 & -740560.491 & 12258392.256 & 508.629 & 0.00780 & 0.00825 & 0.04475 \\
\hline КТРH & 2014 & 12 & 17 & -740601.733 & 12276835.403 & 103.832 & 0.00555 & 0.00647 & 0.02474 \\
\hline MJEN & 2014 & 12 & 17 & -757798.310 & 12239250.082 & 31.335 & 0.00468 & 0.00567 & 0.02458 \\
\hline
\end{tabular}


Untuk mendapatkan pergerakan yang sebenarnya dari setiap stasiun pengamatan GPS, maka dilakukan konversi dari koordinat (utara, timur, dan up) menjadi kecepatan pergerakan (utara, timur, dan up). Pada Gambar 6 ditampilkan vektor kecepatan pergerakan di setiap stasiun pengamatan yang merupakan gradien dari model linier deret waktu perubahan posisi dengan elips kesalahan $5 \mathrm{~mm}^{[13]}$.

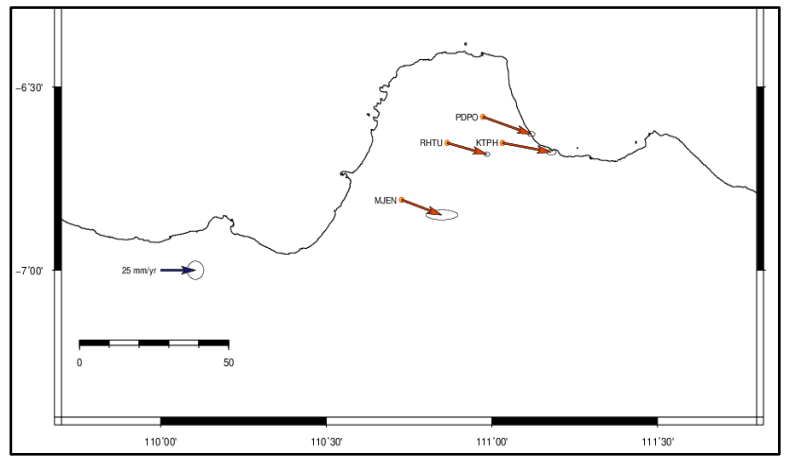

Gambar 6. Vektor Kecepatan Pergerakan Stasiun Pengamatan.

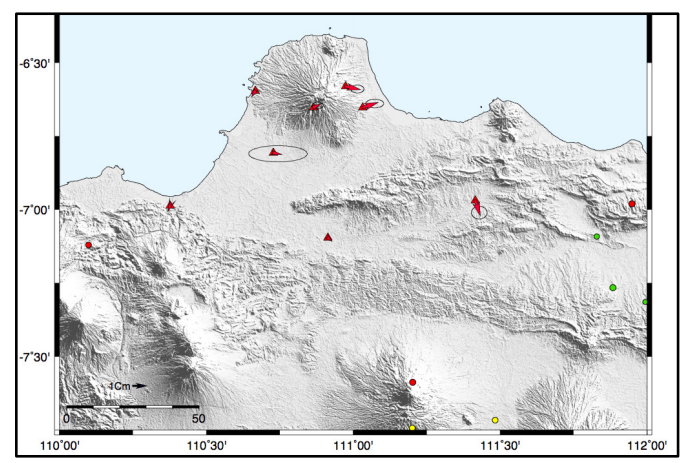

Gambar 7. Vektor Kecepatan Pergerakan Tanpa Pengaruh Pergerakan Lempeng.

Untuk mengetahui pola deformasi lokal, vektor kecepatan pergerakan pengamatan dikoreksi dengan vektor kecepatan pergerakan model. Kecepatan pergerakan model merupakan kecepatan pergerakan yang merepresentasikan pergerakan rotasi blok Sunda[14], sehingga, vektor kecepatan akan terlihat seperti Gambar 7. Hasil analisis menggunakan software GAMIT 10.4 dapat disimpulkan bahwa sampai dengan tahun 2014 pergeseran di sekitar Muria didominasi oleh pergerakan lempeng (rotasi blok Sunda) dengan kecepatan 2,2 cm/tahun, dan ketelitian pengamatan GPS selama 3 tahun berkisar 3-8 $\mathrm{mm}$.

Dari nilai kecepatan pergerakan, dapat ditentukan distribusi nilai regangan untuk wilayah Muria. Distribusi nilai regangan meliputi regangan principal (Gambar 8) dan regangan geser maksimum (Gambar 9). Pergeseran yang sangat lokal mengindikasikan adanya deformasi di sekitar tengah dan utara dari Muria dengan nilai pergeseran sebesar 2$3 \mathrm{~mm} /$ tahun. Perhitungan regangan menunjukan adanya regangan di wilayah utara Muria dengan nilai sebesar $2 \times 10^{-2}$ microstrain/tahun, nilai ini masih diatas nilai regangan yg konsisten sebesar $5 \times 10^{-8}$ microstrain/tahun ${ }^{[15]}$.

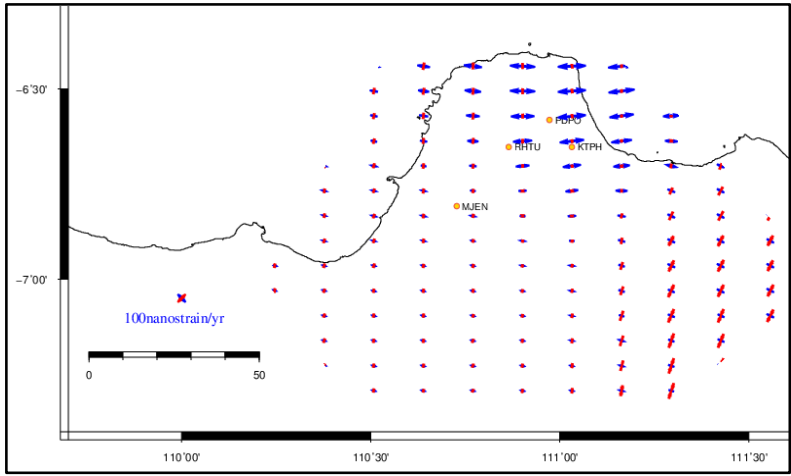

Gambar 8. Distribusi Regangan Principal Wilayah Muria.

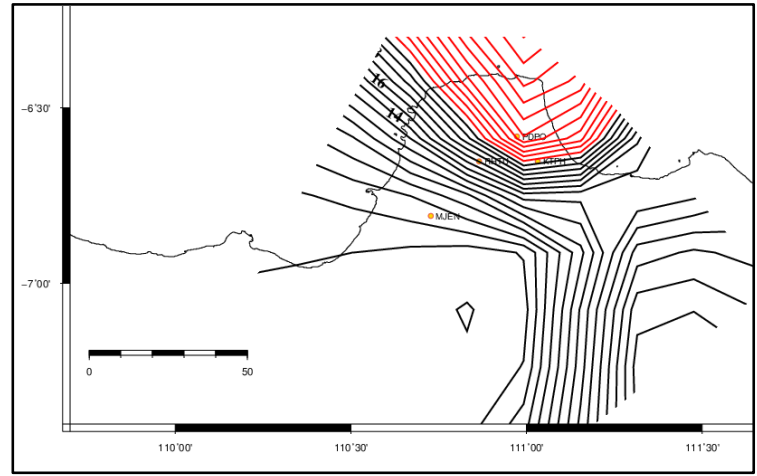

Gambar 9. Distribusi Regangan Geser Maksimum Wilayah Muria. 


\section{KESIMPULAN}

Karakteristik deformasi Gunung Muria periode tahun 2010 - 2014 menunjukkan bahwa terdapat pergeseran regional di sekitar Muria yang didominasi oleh pergerakan lempeng (rotasi blok Sunda) dengan kecepatan 2,2 cm/tahun, serta pergeseran lokal di tiap 5 lokasi BM dengan kecepatan 2-3 mm/tahun. Perhitungan regangan menunjukan regangan di wilayah Utara Muria dengan nilai sebesar $2 \times 10^{-2}$ microstrain/tahun, dan nilai ini masih di atas nilai regangan yg konsisten ( $5 \times 10^{-8}$ microstrain/ tahun), hal ini mengindikasikan adanya aktivitas gerakan tanah.

\section{DAFTAR PUSTAKA}

[1]. INTERNATIONAL ATOMIC ENERGY AGENCY, "Review Of Status Of Site Evaluation Studies At Muria Peninsula NPP Site", Jakarta, Indonesia 13 - 17 February 2006.

[2]. KUANG, S.,"Geodetic Network Analysis and Optimal Design : Concept and Applications", Ann Arbor Press Inc., Chelsea, Michigan, 1996.

[3]. ABIDIN Z. HASANUDDIN, dkk., "Karakteristik Deformasi Gunungapi Ijen dalam periode 2002- 2005 Hasil Estimasi Metode Survei GPS", PROC. ITB sains \& Tek, Vol 39 A, No 1\&2, 2007.

[4]. "Pengukuran Global Positioning System Untuk Pemantauan Deformasi Gunung Muria Dalam Rangka Pembangunan Pembangkit Listrik Tenaga Nuklir", Institut Teknologi Bandung, Bandung, 2011.

[5]. ABIDIN, Z. HASANUDDIN, "Penentuan Posisi Dengan GPS Dan Aplikasinya", PT.Pradnya Paramita, Cetakan Ketiga, Jakarta, 2006.

[6]. ABIDIN, Z. HASANUDDIN, "Modul 7 Pendahuluan Metode Survey GPS", Jakarta, 2007.

[7]. NUGROHO, A., “Modifikasi Benchmark Dan Pengaruhnya Terhadap Ketelitian Pengukuran Deformasi Di Muria" Jurnal Pengkajian Sistem Energi Nuklir volume 15, nomor, Juni 2013.

[8]. NUGROHO, A., dkk., "Laporan Teknis Pengukuran Deformasi Muria”, BATAN, Jakarta, 2014.

[9]. “ـaring Kontrol Horizontal, Standard Nasional Indonesia SNI 19-6724-2002", Badan Standardisasi Nasional, Jakarta, 2002.

[10]. McBIRNEY A. R., LEONELLO SERVA, M. GUERRAB, CHARLES B. CONNORS, "Volcanic and seismic hazards at a proposed nuclear power site in central Java", Journal of Volcanology and Geothermal Research, 2003.

[11]. GUNAWAN, DEDE, "Pemodelan Mekanisme Deformasi Post-Seismic Gempa Bengkulu 2007", Tugas Akhir Program Studi Teknik Geodesi dan Geomatika, 2008.

[12]. CHRZANOWSKI, "Geotechnical and Other Non-Geodetic Method in Deformation Measurement", Technical Report, Department of Surveying Engineering, University of New Brunswick, Frederiction, Canada, 1986.

[13]. ANDREAS, HERI dkk., "Implikasi Co-Seismic dan Post-Seismic Horizontal Displacement Gempa Aceh 2004 Terhadap Status Geometrik Data Spasial Wilayah Aceh dan Sekitarnya", Kelompok Keahlian Geodesi Departemen Teknik Geodesi Institut Teknologi Bandung, 2007.

[14]. _ Pengukuran Global Positioning System Untuk Pemantauan Deformasi Gunung Muria Dalam Rangka Pembangunan Pembangkit Listrik Tenaga Nuklir", Institut Teknologi Bandung, Bandung, 2014. 
[15]. BOCK, YEHUDA et al., "Crustal Motion in Indonesia From Global Positioning System Measurements",Journal of Geophysical Research Vol. 108, No.B8, 2367, doi: 10.1029/2001JB000324, 2003. 